\title{
NOTES
}

\section{FEDERAL COURT REVIEW BY EXTRAORDINARY WRIT: A CLOGGED SAFETY VALVE IN THE FINAL JUDGMENT RULE}

THE final judgment rule ${ }^{1}$ denies litigants in federal court immediate review of most interlocutory orders ${ }^{2}$ by prohibiting appeal from a decision on a "preliminary or subsidiary point" until after final judgment. ${ }^{3}$ Congress enacted the rule to keep appellate courts' work load within manageable limits and to prevent appeals designed to harass opponents during trial." Yet litigants often desire immediate review of adverse interlocutory orders merely to preclude added delay and expense at the trial stage. And in some instances, immediate reversal may avert injury which postponed appeal could not repair. ${ }^{\circ}$ In others, the litigant who can obtain no review of a "preliminary" order is left without appeal at any stage. ${ }^{7}$

1. The rule is embodied in several statutes. 28 U.S.C. $\$ 1291$ (Sunp. 1952); 15 U.S.C. $\$ 29$ (Supp. 1952); 18 U.S.C. $\$ 3731$ (Supp. 1952). For a discussion of these statutes and others governing appeal, see 6 Moone, FEDERAL PRACTICE fid 54.04-54.09 (2d ed. 1953) (hereinafter cited as MOONE).

2. There are a few exceptions to the rule. Interlocutory appeal is granted extensively in bankruptcy and admiralty proceedings, and in a limited number of civil actions. Sce 6 Mooke I 54.04 nn.13-15. Federal Rule 54(b) permits apptal of an order "finally" disposing of one claim in a multiple claims suit, even though the entire suit has not terminated at the trial stage. See Note, 62 YaLE L.J. 263 (1953). Judicial decision has authorized immediate appeal from three types of rulings: collateral orders, immediately executable decrees disposing of property, and "separate" orders in multiple-party suits. Courts consider such orders final when made, and hence they are not strictly exceptions to the final judgment rule. Id. at 268 n.36.

3. 1 Black, Judgarents $\$ 21$ (1891).

Because no one has defined "final judgment" comprehensively, its meaning is a frcquent subject of litigation. Those who advocate modification of the rule cite this continuing dispute as one of the rule's primary disadvantages. See 6 MLoone 754.43 ; Cricl;, The Ftinol Iudgment as a Basis for Appeal, 41 YALE L.J. 539 (1932); Sunderland, The Problcris of Appellate Review, 5 Texas L. Rev. 126 (1927); Notes, Proposals for Intcrloculory Appeals, 58 YaLe L.J. 1186 (1949); The Final Judgnest Rule in the Fcderal Courts, 47 Cor. L. REv. 239 (1947).

4. See Notes, 58 Yale L.J. 1186 (1949); 47 CoL. L. Rev. 239 (1947).

5. See, e.g., Roche v. Evaporated Milk Ass'n, 319 U.S. 21, 30 (1943); Hydraulic Press Mffg. Co. v. Moore, 185 F.2d S00, 802-03 (Sth Cir. 1950).

6. See notes 37-46 infra and accompanying text.

7. See notes $27-36$ infra and accompanying text.

Hardship which the final judgment rule imposes upon some litigants has prompted suggestions for modification of the rule. See authorities cited second paragraph, sisfra note 3. 
Despite the final judgment rule, both the Supreme Court and the federal courts of appeals can reverse interlocutory orders without delay by issuing to lower courts extraordinary writs of common law certiorari, ${ }^{8}$ mandamus, or prohibition. $^{9}$ Although review by writ procedurally resembles statutory appeal, ${ }^{10}$ the writ seeker faces obstacles which do not confront the appellant. First, he must attempt to meet unusually ill-defined standards. Federal courts dispose of most writ applications summarily, ${ }^{11}$ and those opinions written supply few guides for future petitioners. ${ }^{12}$ Secondly, courts construe existing standards restrictively. ${ }^{13}$ Federal appellate courts are empowered to grant writs

8. The common law writ of certiorari should not be confused with the statutory writ of certiorari. The statutory writ is the principal device by which a petitioner normally obtains review by the Supreme Court; the common law writ is issued by both the Supreme Court and the courts of appeals only in extraordinary cases. See Roserts \& Kinkiram, Jurisdiction of the Supreane Court of the United States $\$ 309$ (Wolfson \& Kurland eds. 1951).

9. "The Supreme Court and all courts established by Act of Congress may issue all writs necessary or appropriate in aid of their respective jurisdictions and agreeable to the usages and principles of law." 28 U.S.C. $\$ 1651$ (a) (Supp. 1952). Certiorari, mandamus, and prohibition were used at common law. See Ferris, ExtraoronNARY Legal RENEDIES 177, 218, 414 (1926).

The Supreme Court has expressed unwillingness to decide, by issuing writs, questions not of public importance or "otherwise appropriate," unless the case would have come directly to it in the normal course of appeal. See Ex parte Peru, 318 U.S. 578, 584-5 (1943) (quoting Ex parte United States, 287 U.S. 241, 248-9 (1932)).

Of the extraordinary remedies, only the writs of common law certiorari, prohibition, and mandamus which issue to lower courts will be discussed here, because they alone are used interchangeably to complement the appellate process. Although these writs performed different functions at common law, courts at present treat them alike and petitioners often apply for them in the alternative.

10. Litigants file petitions similar to briefs and may argue before appellate courts, which have power to reverse erroneous orders made below. Of course, procedural details vary in different courts. See, e.g., State of Tennessee v. Taylor, 169 F.2d 626, 628 (6th Cir. 1948). See RoBerts \& Kirkhanr, op. cit. sipra note 8, at 585; Darden, Mandamis, 24 Mrss. L.J. 95,96 (1952). Courts often afford relief-though technically withholding the writ itself-by serving notice on the erring judge that unless he modifics his order a writ will issue. E.g., United States v. Hall, 9th Cir., Aug. 4, 1953.

11. Examination of the Docket Book and files of the Second Circuit, for instance, reveals that of the forty-seven writ petitions filed with that court between December 30 , 1947 and December 30, 1952, thirty-two were denied without opinion. There were four full opinons, five per curiam opinions, three opinions in parallel appeals; and three petitions were withdrawn before action was taken upon them.

The large number of denials without opinion may result in a falsely encouraging impression of a petitioner's chances for obtaining a writ. Counsel may overlook the numerous summary denials and see only that writs issued in a relatively high percentage of the cases in which opinions are reported. See compilation in 44 FED. DiG. 193-8 (Supp. 1953).

12. For example, it is a common practice for a court to assume, without deciding, that it has power to issue a writ in a particular case and then base its decision on other grounds. See, e.g., Ex parte Bakelite Corp., 279 U.S. 438, 448 (1929); In re Greene, 160 F.2d 517 (3d Cir. 1947).

13. See, e.g., Ex parte Fahey, 332 U.S. 258, 259-60 (1947); United States v. Byers, 144 F.2d 455, 456 (2d Cir. 1944). 
"in aid of their respective jurisdiction." 14 Although controversy has persisted over the meaning of that phrase, ${ }^{15}$ it is currently interpreted as authorizing courts to use writs for two purposes only: first, to police lower courts by compelling them to act within their jurisdiction, ${ }^{16}$ or second, to review cases where there is no appeal ${ }^{17}$ or where litigants relying on statutory appeal would suffer more than the ordinary hardship of delay. ${ }^{18}$ And most judges actually will issue a writ only when doing so serves both purposes at once. ${ }^{19}$

A jurisdictional error in a lower court's interlocutory order justifies issuing a writ in its policing role. ${ }^{20}$ The lower court may err jurisdictionally at the outset by refusing to hear a case within its jurisdiction ${ }^{21}$ or by trying a case in which it lacks jurisdiction over the subject matter ${ }^{20}$ or parties. ${ }^{23}$ And a court which initially had jurisdiction orer a case may exceed its authority by contravening a rule or statute of procedure. ${ }^{24}$ Thus the statute which permits venue

14. 28 U.S.C. $\$ 1651$ (Supp. 1952).

15. See, e.g., the dispute between Judge Learned Hand and Judge Frank in Magnetic Engineering \& Mfg. Co. v. Dings Mfg. Co., 178 F.2d $S 66$ (2d Cir. 1950).

16. "The traditional use of the writ in aid of appellate jurisdiction both at cummon law and in the federal courts has been to confine an inferior court to a lawiul exercise of its prescribed jurisdiction or to compel it to exercise its authority when it is its duty to do so." Roche v. Evaporated Milk Ass'n, 319 U.S. 21, 26 (1943). The cases contain numerous variations on this theme.

17. See notes $27-36$ infra and acompanying text.

18. See notes 37-53 infra and accompanying text.

19. See, e.g., United States Alkali Ass'n v. United States, 325 L.S. 19, 202-03 (1945) ; Kanatser v. Chrysler Corp., 199 F.2d 610, 615-16 (10th Cir. 1952), cert. dericd, 344 U.S. 921 (1953). The Supreme Court has stated that common law writs may be granted or withheld in the sound discretion of the courts, and that issuing a writ is not a question of power, but one of appropriateness. Ex parte Peru. 318 U.S. 578, 584 (1943); Roche v. Evaporated Miilk Ass'n, 319 U.S. 21, 25-6 (1943). See Wolfson, Extraordivary' Writs in the Supreme Court Since Ex Parte Peru, 51 CoL L. Rev. 977 (1951). But this has not made it easier to procure a writ. For example, in the Roclse case the Supreme Court reversed the Ninth Circuit's use of mandamus as inappropriate. And courts of appeals have continued to question their power to issue writs. See, c.g., Clinton Foods v. United States, 18S F. 2d 289, 292 (4th Cir.), cert. denicd, 342 U.S. 825 (1951) ; Hartford Acc. \& Indem. Co. v. Interstate Equip. Corp., 176 F.2d 419, 420 (3d Cir.), cert. denied, 338 U.S. $S 99$ (1949). Wolfson, supro at 992.

20. See note 16 supra. Some courts will issue a vrit only if the jurisdictional error is clear. See cases cited note 60 infra.

21. See, e.g., Ex parte Kawato, 317 U.S. 69 (1942) (on writ petition, resident enemy alien held not barred from courts by $\S 7$ of the Trading with the Enemy Act); United States v. Hall, 145 F.2d 781 (9th Cir. 1944), cert. denicd, 324 U.S. 871 (1945) (mandamus to judge erroneously refusing to hear case on ground that attorney had no authority to prosecute condemnation proceedings on behalf of the United States); cf. Czuczka v. Rifkind, 160 F.2d 308 (2d Cir. 1947).

22. See, e.g., Petition of Therianos, 171 F.2d 886 (3d Cir. 1948); Ward Baling Co. v. Holtzoff, 164 F.2d 34 (2d Cir. 1947).

23. Blaw-Knox Co. v. Lederle, 151 F.2d 973 (6th Cir. 1945). Cf. Hydraulic Press Mifg. Co. v. Moore, 185 F.2d 800 (Sth Cir. 1950).

24. Kanatser v. Chrysler Corp., 199 F.2d 610 (10th Cir. 1952), cert. denicd, 344 U.S. 921 (1953) (Fed. R. Civ. P. 59(d), new trial); United States v. Kirlpatricl; 186 F.2d 
changes for convenience, limits accessible forums to those in which the plaintiff could have brought his action originally. ${ }^{25}$ Courts of appeals therefore will use writs to void, as jurisdictional errors, transfers to districts where process could not have reached the defendant. ${ }^{20}$

To invoke writs as instruments of review, litigants must show that ordinary channels of appeal offer them no adequate remedy. Appeal may be nonexistent; lower court action may have obstructed it where it is available; or, thirdly, where appeal is available and unobstructed, the lower court's order may be abnormally detrimental to one party.

In a few instances, writs constitute the sole means of reviewing lower court error. There is no appeal from a district judge's noncompliance with the statute ${ }^{2 \tau}$ ordering him to summon a three-judge court in a suit to enjoin state officers from enforcing an allegedly unconstitutional statute. ${ }^{28}$ Therefore the Supreme Court considers the writ of mandamus proper to force district judges to convene three-judge courts. ${ }^{20}$ The Court has utilized common law certiorari to examine thwarted attempts to reach the courts of appeals. ${ }^{30}$ And there is no other feasible way to review judicial disregard of the federal statute ${ }^{\mathbf{} 1}$ waiving prepayment of fees and costs for impecunious appellants. ${ }^{32}$ Mandamus has issued to remand to state courts criminal prosecutions improperly removed to federal court. ${ }^{33}$ States can neither appeal these removals when made nor

393, (3d Cir. 1951) (Admiralty Rule 431/2, reference to master); Stratton v. St. Louis S.W. Ry., 282 U.S. 10 (1930) (three-judge court statute); Foster-Milburn Co. v. Knight, 181 F.2d 949 (2d Cir. 1950) (venue statute).

25. 28 U.S.C. $\S 1404$ (a) (Supp. 1952).

26. Foster-Milburn Co. v. Knight, 181 F.2d 949, 951 (2d Cir. 1950); cf. Clinton Foods v. United States, 188 F.2d 289, 292-3 (4th Cir.), cert. denied, 342 U.S. 825 (1951); Shapiro v. Bonanza Hotel Co., 185 F.2d 777, 780-1 (9th Cir. 1950).

27. 28 U.S.C. $\$ 1253$ (Supp. 1952).

28. Stratton v. St. Louis S.W. Ry., 282 U.S. 10, 15-16 (1930).

29. Ex parte Bransford, 310 U.S. 354, 355 (1940). The fact that three-judge court decisions are directly appealable to the Supreme Court, see Stratton v. St. Louls S.W. Ry., supra note 28, is another reason why the Supreme Court will grant mandamus here.

But the Court has construed the statute restrictively. For example, although district judges may not dismiss applications for three-judge courts on their merits, they may for lack of federal jurisdiction. Ex parte Poresky, 290 U.S. 30 (1933). And see Moone, Commentary on the U.S. Judicial Code, text accompanying f 0.03(20) un.19-28 (1949).

30. See, e.g., House v. Mayo, 324 U.S. 42 (1944) (district judge refused to issue certificate necessary to appeal from habeas corpus decision); In re 620 Church St. Building Corp., 299 U.S. 24 (1936) (Supreme Court affirming Seventh Circuit's refusal to allow appeal from district court confirmation of reorganization plan); In re Chetwood, 165 U.S. 443 (1897) (petitioners" erroneously enjoined by district court from prosecuting their suit in state court or applying for writ of error); cases cited note 32 infra.

31. 28 U.S.C. $\S 1915$ (Supp. 1952).

32. Steffler v. United States, 319 U.S. 38 (1943); cf. Roberts v. United States District Court, 339 U.S. 844 (1950).

33. Thus mandamus has issued to remand cases erroneously removed under the statute, 28 U.S.C. $\S 74$ (1946), allowing removal of state criminal prosecutions in 
obtain review after a defendant's verdict. ${ }^{34}$ Hence the Court has reviewed by writ to protect the sovereign interests of the states. ${ }^{35}$ But the explicit prohibition against reviewing a federal court's order remanding a case to state court will not be circumvented by writ. ${ }^{30}$

Where Congress has provided appellate review, courts may nevertheless issue writs "in aid of the appellate jurisdiction which might otherwise be defeated by the unauthorized action of the court below."3i Appeal from final judgment, although possible, is valueless to the litigant when lower court errors threaten to snuff out the issues before appeal can be taken. ${ }^{39}$ A trial judge may defeat appellate jurisdiction by mistakenly ordering proceedings before him stayed pending a state court's determination of issues which are not in fact of peculiar state concern. ${ }^{33}$ The decision of the state court may bind the federal court by collateral estoppel or-if the cause of action is identical in both courts-by res judicata. ${ }^{40}$ In addition, the lower court may emasculate appeal by keeping the case at the trial stage indefinitely. ${ }^{\prime 1} A$ civil litigant therefore can procure mandamus to force a district judge to make a

which state constitutions or laws deprive defendants of civil rights. Sce, c.g., Virginia v. Rives, 100 U.S. 313 (1879); Kentucliy v. Powers, 201 U.S. 1 (1905). The court has similarly remanded cases removed under the statute, 2S U.S.C. $\$ 76$ (1946), allowing removal of state criminal prosecutions of federal revenue officers for offences committed while performing their duties. See, e.g., Colorado v. Symes, 286 U.S. 510 (1932); Virginia v. Paul, 148 U.S. 107 (1893)

34. See Maryland v. Soper (No. 1), 270 U.S. 9, 30 (1916) ; cf. United States v. Sanges, 144 U.S. 310 (1S92).

35. Maryland v. Soper (No. 1), supra note 34, at 29-30. But where state sovereignty was not at stake, a federal court denied mandamus when issuance promised to override the federal criminal appeals statute. United States v. Bondy, 171 F.2d (42 (2d Cir. 1948). And another court withheld mandamus in a civil case concerning a state, but where the state's prerogative to try in its own courts violations of its laws was not involved and where appeal after final judgment was available. Pennsylvania Turnpilie Comm. v. Welsh, 18S F.2d 447 (3d Cir. 1951).

36. In re Pennsylvania Co., 137 U.S. 451 (1890); Kloeb v. Armour \& Co., 311 U.S. 199 (1940).

37. McClellan v. Carland, 217 U.S. 26\$, 280 (1916).

38. Ibid.

39. Originally district judges had no discretion to stay federal suits pending the outcome of state court proceedings, and appellate courts granted writs to vacate all stay orders. See, e.g., MicClellan v. Carland, 217 U.S. 268, 252 (1910); Barber Asphalt Paving Co. v. Morris, 132 Fed. 945, 947-8 (8th Cir. 1904). At present, district judges have some discretion to issue stay orders, particularly in cases where critical issues are peculiarly of state concern. See Mottolese v. Kaufman, 176 F.2d 301, 302 (2d Cir. 1949). Predicting the success of writ applications is especially difficult here because appellate judges disagree on the boundaries of district court discretion to order proceedings stayed. See, e.g., Jewell v. Davies, 192 F.2d 670 (6th Cir. 1951); Mottolese v. Kauman, suspra; In re President \& Fellows of Harvard College, 149 F.2d 69 (1st Cir. 1945).

40. See cases cited note 39 supra.

41. See, e.g., Steccone v. Morse-Starrett Products Co., 191 F.2d 197 (9th Cir. 1951); Schwab v. Coleman, 145 F.2d 672 (4th Cir. 1944). 
decision on the merits of his case, ${ }^{42}$ while a criminal defendant can obtain the writ to enforce his right to speedy trial. ${ }^{43}$ Similarly, mandamus will issue to compel lower courts to perform such ministerial acts as supplying papers necessary to the commencement or maintenance of suit.44 After an appellant has won on appeal, he may suffer on remand from the lower court's noncompliance with instructions of the superior court. ${ }^{45}$ Litigants in this predicament have always obtained mandamus. ${ }^{46}$

Appellate courts have considered appeal inadequate in a few situations where it is available and lower courts have not impaired it. Writs have issued to void orders which directly or indirectly deny a litigant his right to trial by jury, largely because that right is so highly prized that reversal on appeal would be inevitable. ${ }^{47}$ Although courts hold that ordinary inconvenience and expense incurred by a litigant while waiting for appeal will not justify issuing a writ, ${ }^{48}$ they have used writs to save litigants extraordinary detriment, such as that caused by transfers to other venues ${ }^{40}$ or reference of issues to a master

42. E.g., Ex parte Kawato, 317 U.S. 69 (1942) ; Czuczka v. Rifkind, 160 F.2d 30 S (2d Cir. 1947) ; United States v. Hall, 145 F.2d 781 (9th Cir. 1944) ; Schwab v. Coleman, 145 F.2d 672 (4th Cir. 1944).

43. Frankel v. Woodrough, 7 F.2d 796 (8th Cir. 1925); cf. Fowler v. Hunter, 164 F.2d 668, 670 (10th Cir. 1947).

44. See, e.g., Ex parte United States, 287 U.S. 241 (1932) (district judge refused to issue bench warrant on indictment fair on its face and brought by properly constituted grand jury); Ex parte Abdu, 247 U.S. 27 (1918) (clerk of court of appeals declined to file record without deposit to secure costs,) ; Semel v. United States, 158 F.2d 231, 232 (5th Cir. 1946) (application to require that district clerk transmit notice of appeal).

45. See, e.g., United States v. United States District Court, 334 U.S. 258 (1948); In re Chicago, R.I., \& Pacific Ry., 162 F.2d 257 (7th Cir. 1947).

46. "[T] he courts have uniformly held that where a lower court has failed to comply with the mandate of the reviewing court, compliance with the mandate may be compelled by a writ of mandamus." In re Chicago, R.I., \& Pacific Ry., supra note 45, at 258.

47. See, e.g., Ex parte Skinner \& Eddy Corp., 265 U.S. 86 (1924); Bereslavsky v. Caffey, 161 F.2d 499 (2d Cir.), cert. denied, 332 U.S. 770 (1947).

48. See cases cited note 5 supra.

49. Two statutes authorize defendants to contest venue in civil cases: 28 U.S.C. \$ 1404(a) (Supp. 1952) permits transfer "for the convenience of parties and witnesses;" 28 U.S.C. $\$ 1406$ (a) (Supp. 1952) permits transfer or dismissal of cases brought "in the wrong division or district."

Challenges of lower court venue rulings constitute the largest category of writ petitions. Only a small number of these involve $\$ 1406$ (a). E.g., C-O-Two Fire Equipment Co. v. Barnes, 194 F.2d 410 (7th Cir. 1952) ; Gulf Research \& Development Co. v. Leahy, 193 F.2d 302 (3d Cir. 1951), aff'd per curiam, 344 U.S. 861 (1952). Of the many petitioners seeking reversal of $\S 1404$ (a) orders, few have succeeded. The Second Circuit has granted relief when a district judge violated the statute by transferring a case to as venue in which it could not have been brought originally. Foster-Milburn Co. v. Knight, 181 F.2d 949 (2d Cir. 1950). Also see Clinton Foods v. United States, 188 F.2d 289, 292 (4th Cir.), cert. denied, 342 U.S. 825 (1951) ; Shapiro v. Bonanza Hotel Co., 185 F.2d 777, 779-81 (9th $\mathrm{Cir}$. 1950). The Fifth Circuit has employed a writ to prevent retransfer of a case after two mistrials. Atlantic Coast Line Ry. v. Davies, 185 F.2d 766 (5th Cir. 1950). And two courts have granted extraordinary relief when district judges have 
for trial. ${ }^{50}$ In such cases, issuing writs is further justified on the ground that erroneous transfer or reference seldom constitutes reversible error on appral, even though it may jeopardize a litigant's chances of succeeding. ${ }^{51}$ Regardless of the availability or efficacy of appeal, appellate courts have long used the writ of prohibition to prevent lower courts from damaging United States international relations by ordering seizure of foreign ships libeled in American ports. ${ }^{52}$ On this ground, for example, the Supreme Court issued prohibition to forbid a district court from exercising further jurisdiction over a Peruvian vessel after the State Department had recognized the ship's immunity. ${ }^{10}$

Judicial disagreement concerning the standards governing writ issuance seems partially responsible for the currently large number of unsuccessiul petitions. ${ }^{54}$ Most judges will issue a writ only to review an order which embodies a jurisdictional error and from which appeal is inadequate. in a few opinions, courts have completely ignored the adequacy of appeal. More often they have issued writs on the sole ground that appeal was inade-

failed to pass on the issue of convenience because of erroneous constructions of the statute. Wiren v. Laws, 194 F.2d S73 (D.C. Cir. 1951); Paramount Pietures v. Rodney, 186 F.2d 111 (3d Cir.), ccrt. denicd, 340 U.S. 953 (1951). But no court has used extraordinary writs to reverse a district judge's decision on the actual question of convenicnee, although several judges have implied that they might do so if the decision were sufficiently off base. See, e.g., Magnetic Engineering \& $1 \mathrm{ffg}$. Co. v. Dings Mfg. Co., 178 F.2d 850,870 (2d Cir. 1950) ; Ford Motor Co. v. Ryan, 182 F.2d 329, 331-2 (2d Cir. 1950); General Portland Cement Co. v. Perry, 204 F.2d 316, 319 (7th Cir., 1953); Nicol v. Koscincls, 188 F.2d 537, 538 (6th Cir. 1951).

50. See, e.g., Los Angeles Brush MIfg. Corp. v. James, 272 U.S. 701 (1926); MICCullough v. Cosgrave, 309 U.S. 634 (1940); United States v. Kirlogatricl;, 186 F.2d 393 (3d Cir. 1950) (reference to commissioner in admiralty) ; Webster Eicenlohr v. Kalodner, 145 F.2d 316 (3d Cir. 1944) (mandamus granted to limit scope of master's investigation to issues in the case).

51. "[I]t will be extremely difficult for the... [petitioner] to show that it lost the ease because of the handicap of transfer. As for the added cost of trying the case in the new forum it is hard to see how in any event it could be recoverable from the defendant, for the error would be that of the court." Magnetic Engineering \& Mifg. Co. v. Dings Mfg. Co., 178 F.2d 866, 869 (2d Cir. 1950).

52. E.g., Ex parte Peru, 318 U.S. 578 (1943) ; Ex parte Cooper, 143 U.S. 472 (1891) (British vessel forcibly taken into Sitka, Alaska and libeled by a United States Revenus vessel); United States v. Peters, 3 Dall. 120 (U.S. 1795) (American citizen libolcs French corvette in Pennsylvania District Court).

53. Ex parte Peru, supra note 52. But of. Republic of China v. National City Banl: of New York, 194 F.2d 170 (2d Cir. 1952).

54. The Second Circuit has afforded relief to only one of the forty-seren petitioner; who filed their petitions between December 30, 1947 and December 30, 1952. Some of thos: denials were undoubtedly the result of frivolous applications. And some petitions which appeared to satisfy doctrinal requirements failed on their merits. See, c.g., Goodman v. Clancy, 195 F.2d 235 (2d Cir. 1952) ; Ford Motor Co. v. Ryan, 182 F.2d 329 (2d Cir. 1950) ; Mottolese v. Kaufman, 176 F.2d 301 (2d Cir. 1949).

55. See note 19 supra.

56. See, e.g., American Airlines v. Forman, 207 F.2d 230 (3d Cir. 1953) ; Blaw-Kno: Co. v. Lederle, 151 F.2d 973 (6th Cir. 1945). 
quate, even though the lower court's error was not jurisdictional. ${ }^{57}$ Universal acceptance of revised stanclards would save courts and litigants mutch of the time and money they now waste on ill-advised petitions.

Even if doctrine were settled, however, the highly conceptual nature of the distinction between jurisdictional error and "mere" abuse of discretion would still make it difficult to foretell which label a court would apply in a particular case. Theoretically a court errs jurisdictionally by making an order of a kind which it lacks power to issue ; $; 8$ when it abuses its discretion, it has power to make the kind of order it issues but acts unreasonably under the circumstances. But the distinction may be practically impossible for petitioners to draw. Even the courts have floundered in the quagmire they created. While jurisdictional errors tend to be more clearcut, not all of them are obvious. Even to detect a jurisdictional error, the reviewing court often must scrutinize the trial record closely. ${ }^{60}$

Apart from the uncertainty it injects, confining the writs' operation to jurisdictional errors may unfairly deny review to some petitioners for whom appeal would be ineffective; one type of error can be as detrimental as another. It is a Second Circuit policy, for instance, to issue writs correcting interlocttory orders which change venue only if the order embodies a jurisdictional error. ${ }^{61}$ Thus the court will not use writs to review a transfer to a jurisdic-

57. E.g., Wiren v. Laws, 194 F.2d 873 (D.C. Cir. 1951); Paramount Pictures v. Rodney, 186 F.2d 111 (3d Cir.), cert. denied, 340 U.S. 953 (1951); United States v. Kirkpatrick, 186 F.2d 393 (3d Cir. 1950).

58. Even this court-made concept has been criticized as too broad. Sce 6 Mooke, If $54.10[4] \mathrm{nn} .23,24$.

59. One district judge, for instance, refused to change the venue of a case for the convenience of the parties, in the erroneous belief that he lacked power to make the transfer requested. The Third Circuit issued mandamus. It could reasonably have classified the error by any one of three methods. The court could have termed the error jurisdictional on the ground that the district judge refused to determine issues of justice and convenience as required by the statute. Secondly, the error could have been labeled jurisdictional bccause the lower court misjudged its power. In the third place, the abuse of discretion label was applicable; even though the judge had discretion to deny the transfer, he abused it by resting his denial on an erroneous construction of the statute. In fact, the Third Circuit used all of the foregoing rationales, thereby leaving subsequent petitioners guideless at a triple fork in the road. Paramount Pictures v. Rodney, 186 F.2d 111, 116 (3d Cir.), cert. denied, 340 U.S. 953 (1951). Fortunately, the Third Circuit later identificd the Rodney error as an abuse of discretion. Gulf Research \& Development Co. v. Lcahy, 193 F.2d 302, 305 (3d Cir. 1951), aff'd per curiam, 344 U.S. 861 (1952).

60. See, e.g., American Airlines v. Forman, 204 F.2d 230 (3d Cir. 1953); Petition of Therianos, 171 F.2d 886 (3d Cir. 1948).

61. Anthony v. Kaufman, 193 F.2d 85 (2d Cir. 1951), cert. denied, 342 U.S. 955 (1952) ; Arrowhead Co. v. The Aimee Lykes, 193 F.2d 83 (2d Cir. 1951); Magnetic Engineering \& Mfg. Co. v. Dings Mfg. Co., 178 F.2d 866 (2d Cir. 1950). The Third Circuit, on the other hand, has stated that whereas it might correct abuse of discretion in transfer orders, it will not correct jurisdictional errors contained in them. See Gulf Research \& Development Co. v. Leahy, 193 F.2d 302, 305-6 (3d Cir. 1951), aff'd per curiam, 344 U.S. 861 (1952). 
tionally correct district, even though the transfer is erroneous because the new venue is inconvenient and subjects a litigant to exorbitant expenses which he cannot recover on appeal. ${ }^{62}$ Such discrinination seems arbitrary, unless efficient judicial administration demands it.

An obvious rationale for immediately reversing jurisdictional errors only is that their impact on the court system seems particularly serious; where courts exceed their jurisdiction they "endanger" the jurisdiction of appellate courts and the whole judicial structure. Such a fear seems exaggerated. A court similarly exceeds its authority whenever it abuses its discretion or refuses to follow a rule of substantive law enunciated by a superior court. And on a practical level, no error can greatly harm the judicial system so long as an appellate court can police its subordinates by reversing them on appeal after final judgment. ${ }^{63}$

Since jurisdictional errors appear to damage neither litigants nor the judicial system more than other errors do, characterization of lower court mistakes provides no sound standard by which to judge writ petitions. Nevertheless any error is unduly injurious when appeal supplies no effective redress. And appellate courts have power to issue writs where appeal is non-existent or would be ineffectual. ${ }^{\text {bs }}$ Furthermore, issuing writs in such a situation does not violate the policy supporting the final judgment rule, because petitioners will succeed only by showing more than the ordinary hardship of delayed appeal. Therefore the inadequacy of appeal seems the only valid criterion by which to decide that a writ should issue to correct lower court error. ${ }^{66}$

62. See Anthony v. Kaufman; Arrowhead Co. v. The Aimee Lylies; Magnetic Engineering \& Mfg. Co. v. Dings Mfg. Co., supra note 61.

63. If jurisdictional errors were so harmful, it seems unlikely that courts would delay correcting them until after final judgment as they do where appeal is adequate or the error unclear. See notes 19, 20 supra and accompanying text.

64. See text at notes 17,18 sipra.

65. See text at note 4 supra.

66. Even when courts do not ground their decisions on classification of the lower court error, factors other than adequacy of appeal unfortunately influence disposition of writ petitions. For example, the Eighth Circuit recently refused issuance of mandamus to vacate an order transferring a case from one district to another in the same circuit on the ground that such a transfer "cannot in any way impair or defeat the jurisdiction of this court." There the court ignored the fact that extraordinary hardship is present in every transfer to an erroneous venue, whether or not the case leaves the circuit. Carr v. Donohos, 201 F.2d 426 (8th Cir. 1953).

While the Eighth Circuit discriminates against cases transferred rivihis its circuit, the Second discriminates against cases transferred out of its circuit. Although the latter Circuit will correct both jurisdictional error and abuse of discretion in orders dcnying transfer, it will correct only jurisdictional error in orders directing transfer. See cases cited note 62 supra. The hardship of having to maintain suit in an improper venue is "extraordinary" in both instances. Yet they are treated differently on the ground that in the case of transfer, the court of appeals which gains jurisdiction over the action should decide the propriety of venue. As Judge Frank points out in his dissent, "such a procedure 
What constitutes ineffectiveness of appeal should be defined clearly enough to afford predictability and carefully enough to preserve the final judgment rule. Such a definition obviously would include cases in which appeal is nonexistent or obstructed. Where appeal is available and unobstructed, courts may stretch the concept of extraordinary hardship. ${ }^{67}$ For example, they now employ writs to furnish jury trial immediately, even though inaction until final judgment would produce only the normal inconvenience of delayed appeal..$^{68}$ But most doctrines need a safety valve to accommodate unanticipated or especially deserving claims. Stifling such clearly confined aberrations would accomplish little. ${ }^{69}$ On the other hand, if widespread interlocutory appeal is desired, the final judgment rule-not the scope of the writs-should change. Barring that, the foregoing resolution of the conflicting demands for immediate review and postponed appeal appears to draw a boundary, clearer and more just, around the writs' domain.

involves, necessarily, considerable expense for the [petitioner]. . . He must now reprint, at least in part, the transcript and his brief, and must also pay his lawyer the expense of a trip to Chicago and (presumably) another fee for the oral argument in the Seventh Circuit." Magnetic Engineering \& Mfg. Co. v. Dings Mfg. Co., 178 F.2d 866, 870-1 (2d Cir. 1950).

Without even mentioning extraordinary hardship in its opinion, the Third Circuit recently denied a petition challenging lower court jurisdiction over the case. Its rationale was that the alleged jurisdictional error was not clear, and that the district judge considered the matter in dispute carefully. American Airlines v. Forman, 204 F.2d 230 (3d Cir. 1953).

67. U.S. Alkali Export Ass'n v. United States, 325 U.S. 196 203-04 (1945) (ordinary hardship to litigant, plus "frustration of Congressional policy," justifies writ); cf. Kanatser v. Chrysler Corp., 199 F.2d 610 (10th Cir. 1952), ccrt. denicd, 344 U.S. 921 (1953) (writ granted over convincing dissent finding no extraordinary hardship).

68. Thus, in a typical jury trial case, the Third Circuit said:

"Appeal, after an abortive trial to the court, would be clearly an inadequate remedy." Canister Co. v. Leahy, 191 F.2d 255, 257 (3d Cir. 1951).

Whereas, in a case not involving jury trial, the same court said:

"The mere fact that the petitioner will be put to the inconvenience of what may prove to be a wholly abortive trial is an argument which might be addressed to Congress in support of legislation authorizing interlocutory appeals, but does not constitute grounds for invoking mandamus power."

Gulf Research \& Development Co. v. Leahy, 193 F.2d 302, 304-05 (3d Cir. 1951), aff'd per curiam, 344 U.S. 861 (1952).

69. Use of writs to ensure jury trial is a well established practice. See Ex partc Simons, 247 U.S. 231 (1917) ; Ex parte Peterson, 253 U.S. 300 (1920); Ex parte Skinner \& Eddy Corp., 265 U.S. 86 (1924); Bereslavsky v. Caffey, 161 F.2d 499 (2d Cir.), cert. denicd, 332 U.S. 770 (1947) ; Goldblatt v. Inch, 203 F.2d 79 (2d Cir. 1953); Petsel v. Riley, 192 F.2d 954 (8th Cir. 1951) ; Canister Co. v. Leahy, 191 F.2d 255 (3d Cir. 1951); In re Pan-American Life Ins. Co., 188 F.2d 833 (5th Cir. 1951). 